\title{
Pemberdayaan Siswa Melalui Penerapan Program Health Promotion Model Sebagai Upaya Pencegahan Covid-19
}

\author{
Reza Indra Wiguna*1, Menap², Lalu Hersika Asmawariza ${ }^{3}$, Lalu Muhammad Sadam Husen4, \\ D Mustamu Kamal Pa'ni' ${ }^{5}$ Suswinda Yulisutomo6, Lia Arian Apriani ${ }^{7}$ \\ 1,2,3,4,5,6,7 Fakultas Kesehatan, Universitas Qamarul Huda Badaruddin Bagu \\ *e-mail: rezawiguna13@gmail.com ${ }^{1}$, hmenap06@gmail.com ${ }^{2}$, laluhersikariza@gmail.com ${ }^{3}$, \\ lalusadam68@gmail.com ${ }^{4}$,dmustamuqamal@gmail.com ${ }^{5}$, suswindayulisutomo@gmail.com ${ }^{6}$, \\ liaarian@gmail.com ${ }^{7}$
}

\begin{abstract}
Health Promotion Model (HPM) is a model concept of changing attitudes and behavior characterized by increased knowledge of the health information. This model is used during community service activities to empower student groups in efforts to handle and prevent Covid-19 transmission in the school. The targets of this empowerment activity are students who are members of the PMR, UKS and OSIM organizations of the Islamic Senior High School of Qamarul Huda in Central Lombok, which consists of 20 students with 9 male students and 11 female students. These service activities are provided in the form of health education and health training. Educational materials provided regarding Covid-19; transmission of Covid-19 in school environments; and then the 5-M health protocol material, the material is delivered with lecture method, while training materials and simulations on the 6 steps of washing hands; how to make hand sanitizer; and simulating how to use mask correctly. Empowerment activities for Islamic Senior High School of Qamarul Huda students through the application of the HPM program method have a positive impact, namely in increasing students' knowledge and attitudes about how to handle and prevent Covid-19 transmission in the school environment
\end{abstract}

Keywords: Covid-19; Health Promotion Model; Senior High School; Student

\begin{abstract}
Abstrak
Model promosi kesehatan merupakan model konsep perubahan sikap dan perilaku yang ditandai dengan meningkatnya pengetahuan tentang informasi kesehatan pada seseorang. Model ini digunakan pada saat kegiatan pengabdian kepada masyarakat untuk memberdayakan kelompok siswa dalam upaya penanganan dan pencegahan penularan Covid-19 di sekolah. Sasaran kegiatan pemberdayaan ini adalah siswa-siswi yang tergabung dalam organisasi PMR, UKS dan OSIM Madrasah Aliyah Qamarul Huda Lombok Tengah yang terdiri dari 20 siswa dengan 9 siswa laki-laki dan 11 siswa perempuan. Kegiatan pengabdian ini diberikan dalam bentuk pendidikan kesehatan dan pelatihan. Materi edukasi yang diberikan seputar; Covid19; penularan Covid-19 di lingkungan sekolah; kemudian materi protokol kesehatan 5M, materi tersebut disampaikan dengan metode ceramah, sedangkan materi simulasi dan pelatihan yang telah dilakukan mengenai; latihan 6 langkah cuci tangan; cara membuat hand sanitizer; dan mensimulasikan cara menggunakan masker dengan benar. Kegiatan pemberdayaan siswa Madrasah Aliyah Qamarul Huda melalui penerapan program HPM (Health Promotion Model) memberikan dampak positif yaitu dalam meningkatkan pengetahuan dan sikap siswa tentang cara penanganan dan pencegahan penularan Covid-19 di lingkungan sekolah.
\end{abstract}

Kata kunci: Covid-19; Health Promotion Model; Madrasah Aliyah; Siswa

\section{PENDAHULUAN}

World Health Organization (WHO) telah menetapkan coronavirus disease 2019 atau Covid19 sebagai pandemi global sejak bulan maret 2020, hal ini membuat masyarakat dunia semakin waspada dengan penyebaran virus corona (Dong \& Bouey, 2020). Virus SARS-CoV-2 ditemukan pertama kali di Wuhan pada bulan Desember tahun 2019 (Daniel, 2020). Penyebaran Covid-19 yang awalnya hanya terjadi di China kemudian menyebar hampir ke seluruh negara termasuk di Indonesia. Berdasarkan data angka kejadian Covid-19 di seluruh dunia pada tanggal 15 Mei 2021 
sudah mencapai angka 162.889.975 kasus, Amerika menempati peringkat pertama dengan angka kejadian 33.669.344, sedangkan di Indonesia kasus terkonfirmasi sudah berada di angka 1.736.670 kasus (Kementerian Kesehatan Republik Indonesia et al., 2020; WHO, 2020).

Hampir diberbagai wilayah provinsi di Indonesia terjadi peningkatan kasus Covid-19, termasuk di provinsi Nusa Tenggara Barat (NTB) data terakhir Covid-19 di pertengahan bulan Mei 2021 dilaporkan sebanyak 12,858 kasus (Dinkes Prov.NTB, 2021). Juru bicara Satgas Penanganan Covid-19 mengatakan penambahan kasus tersebut menunjukkan tingkat kepatuhan masyarakat terkait penerapan protokol kesehatan menghadapi pandemi Covid-19 masih belum optimal (Kementerian Kesehatan Republik Indonesia et al., 2020).

Hal tersebut terbukti dengan berbagai laporan menunjukkan bahwa tingkat kepatuhan masyarakat dalam menjalankan protokol kesehatan masih tergolong rendah. Dari penelitian yang dilakukan oleh Wiranti dkk, (2020) menyebutkan sebanyak 44,6\% masyarakat di Kota Depok masih memiliki pemahaman yang kurang mengenai protokol kesehatan terkait pentingnya memakai masker, mencuci tangan dan menjaga jarak (Wiranti et al., 2020). Hal ini sejalan dengan studi literatur yang dilakukan oleh Sagala, dkk (2020) yang melaporkan tentang pemahaman dan kesadaran masyarakat terhadap pencegahan Covid-19 terkait sikap masyarakat melakukan physical distancing masih tergolong rendah (Sagala et al., 2020).

Lingkungan sekolah ditengah situasi pandemi Covid-19 saat ini menjadi perhatian dari segala pihak, hal ini terlihat dari kebijakan Kemendikbud (Kementerian Pendidikan dan Kebudayaan) hingga tahun ini telah menerapkan kebijakan pembelajaran daring untuk semua jenjang pendidikan di Indonesia, terlebih wacana pembelajaran dari rumah tersebut akan beralih normal secara bertahap pada tahun 2021 ini. Anak sekolah merupakan aset atau modal utama pembangunan di masa depan yang perlu dijaga, ditingkatkan dan dilindungi kesehatannya. Sekolah selain berfungsi sebagai tempat pembelajaran juga dapat menjadi ancaman penularan penyakit seperti Covid-19 jika tidak dikelola dengan baik.

Adanya perubahan proses pembelajaran di tengah pandemi ini tentu menjadi suatu tantangan tersendiri bagi seluruh lembaga Pendidikan sekolah di Indonesia. Damanik mengungkapkan dalam hasil penelitiannya yang dilakukan di sebuah sekolah swasta, bahwa kondisi lingkungan tempat belajar memiliki pengaruh yang sangat signifikan terhadap motivasi belajar siswa sekolah. Lalu bagaimana jika lingkungan belajar sekolah berubah kondisinya dalam keadaan pandemi Covid-19 sekarang ini (Damanik, 2019). Hal ini tentu akan membutuhkan adaptasi serta menimbulkan dampak bagi peserta didik. Lingkungan sekolah di situasi Pandemi Covid-19 saat ini harus diciptakan sepositif dan seaman mungkin (safety) agar motivasi belajar siswa sekolah tetap terjaga baik. Bila lingkungan sekolah aman dan sehat tercipta serta motivasi belajar siswa tinggi, maka akan dapat meningkatkan hasil belajar peserta didik (Damanik, 2019).

Promosi Kesehatan di Sekolah dikembangkan dengan pendekatan holistic meliputi keadaan fisik, mental sosial dan lingkungan (Noviyanti et al., 2020). Konsep ini juga melibatkan keluarga, guru, dan masyarakat lingkungan sekolah untuk berpartisipasi dalam meningkatkan pengetahuan dan kemampuan anak sekolah tentang kesehatan dan menunjukkan makna lingkungan sebagai penyumbang kesehatan anak seperti kondisi fisik sekolah, sanitasi, air bersih dan lingkungan pembelajaran.

Oleh karena itu diperlukan sebuah strategi pendekatan terhadap pihak sekolah dengan upaya kegiatan untuk meningkatkan pemahaman siswa dan guru dengan merubah perilaku mereka kearah perilaku kesehatan yang bersifat promotif dan preventif. Health Promotion Model (HPM) atau Model Promosi Kesehatan merupakan konsep model program perubahan sikap dan perilaku dengan peningkatan pengetahuan informasi kesehatan berdasarkan upaya pada pemberdayaan kemampuan individu atau kelompok di masyarakat untuk meningkatkan derajat kesehatan dan kualitas masyarakat (Pender, 2015).

Model HPM dapat membantu kita sebagai peneliti untuk menolong individu atau masyarakat dalam menghadapi pandemi Covid-19 dalam aspek promosi dan pencegahan 
terhadap faktor resiko penularan Covid-19 dengan strategi pembuatan konten promosi dan capaian target sehat pada kelompok (Pender, 2015). Model promosi HPM ini juga dapat mengidentifikasi faktor risiko terhadap kesehatan dan perilaku yang sudah pernah dilakukan dalam hal kepatuhan terhadap protokol kesehatan Covid-19.

Berdasarkan fenomena latar belakang diatas, maka kami sebagai tim pengmas (pengabdian masyarakat) program studi ilmu keperawatan Universitas Qamarul Huda Badaruddin (UNIQHBA) berupaya untuk menerapkan implementasi dari program model promosi kesehatan HPM (Health Promotion Model) yang digunakan sebagai strategi inovasi memberikan edukasi informasi kesehatan terkait pencegahan penularan Covid-19 di lingkungan sekolah Madrasah Aliyah Qamarul Huda Bagu.

\section{METODE}

Kegiatan pengabdian masyarakat ini dilaksanakan di Lingkungan Universitas Qamarul Huda Badaruddin yang bersebelahan dengan Lingkungan Madrasah Aliyah Qamarul Huda Badaruddin yang beralamat di Jl. H. Badaruddin Desa Bagu Kabupaten Lombok Tengah. Adapun pendekatan yang digunakan adalah Asset Based Community Development. Pendekatan ini menekankan pada inventarisasi aset yang terdapat di dalam kelompok masyarakat yang dipandang mendukung pada kegiatan pemberdayaan masyarakat.

Pelaksanaan kegiatan pengabdian dilakukan pada pertengahan bulan Maret 2021. Kegiatan diawali dengan survey pendahuluan ke lokasi pengabdian, tahapan ini bertujuan untuk mengurus perizinan dan penilaian awal terhadap sasaran sebagai mitra. Berdasarkan hasil wawancara yang didapatkan dari mitra yakni Kepala Sekolah Madrasah Aliyah Qamarul Huda, sekolah tersebut telah memiliki aset organisasi kesiswaan berupa PMR (Palang Merah Remaja), UKS (Usaha Kesehatan Sekolah) dan OSIM (Organisasi Siswa Intra Madrasah). Wawancara dilakukan langsung kepada siswa yang tergabung di UKS, PMR, dan OSIM rata-rata mereka memiliki motivasi belajar yang kuat, hal ini ditunjukkan dengan antusiasme mereka untuk mengikuti kegiatan pelatihan. Walau demikian, keterampilan yang dimiliki oleh para siswa/i yang tergabung di PMR, UKS maupun OSIM masih terbatas karena belum adanya pelatihan khusus dari pihak puskesmas setempat.

Berdasarkan hal tersebut, bersama mitra dari Kepala Sekolah Madrasah Aliyah Qamarul Huda disepakati untuk dilaksanakan pemberdayaan siswa PMR, UKS dan OSIM berupa pelatihan penanganan pengendalian dan pencegahan Covid-19 di Lingkungan Sekolah. Sasaran kegiatan pemberdayaan dan pelatihan ini adalah siswa/I yang tergabung di organisasi PMR, UKS dan OSIM Madrasah Aliyah Qamarul Huda, yang terdiri dari 20 siswa diantaranya 9 siswa dan 11 siswi. Konten dan materi kegiatan pemberdayaan ini merujuk pada "Buku Pedoman Perubahan Perilaku Penanganan Covid-19 dengan Protokol 5M" yang diterbitkan oleh Satgas Covid-19 Republik Indonesia.

Kegiatan pengabdian tersebut diberikan dalam bentuk penyuluhan edukasi kesehatan dan pelatihan kesehatan yang diperlihatkan pada gambar 1. Sasaran kegiatan yakni siswa diberikan materi edukasi tentang Covid-19 dan bagaimana transmisi penularan Covid-19 di lingkungan sekolah kemudian materi protokol kesehatan pencegahan dengan melakukan 5M, materi tersebut disampaikan dalam bentuk ceramah. Sedangkan materi simulasi pelatihan dan praktek langsung mengenai cara pelatihan 6 langkah cuci tangan, cara pembuatan handsanitizer, dan simulasi latihan cara menggunakan masker dan perbedaan macam-macam masker. para peserta juga diberikan juga modul materi yang berisikan materi edukasi Covid-19 dan pelatihan protokol kesehatan $5 \mathrm{M}$, lalu di akhir sesi kegiatan dilanjutkan dengan proses diskusi dan tanya jawab sehingga para siswa sebagai peserta diberi kesempatan untuk menyampaikan hal-hal yang belum dimengerti. 


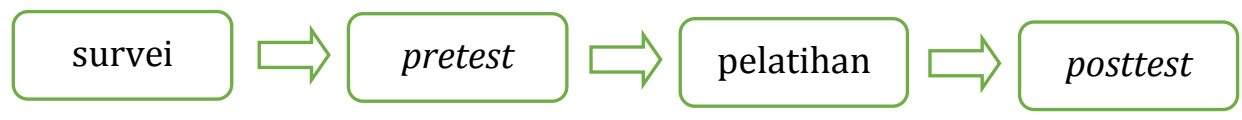

Gambar 1. Alur pelaksanaan kegiatan

Adapun untuk evaluasi kegiatan secara keseluruhan, kepada para peserta disebarkan kuesioner pretest dan posttest untuk melihat sejauh mana keberhasilan kegiatan program HPM ini dengan melihat indikator tingkat pengetahuan peserta terhadap materi edukasi dan pelatihan yang disampaikan. Tingkat pengetahuan peserta dikategorikan menjadi lima indikator pengetahuan, yakni; sangat kurang (0-6); kurang (7-14); cukup (13-18); baik (19-24); sangat baik (25-30). Hasil pretest dan posttest dipaparkan menggunakan statistik deskriptif, pengolahan data mengggunakan program $M S$ Excel untuk melihat hasil dari perbedaan rata-rata (mean) dari tingkat pengetahuan peserta.

\section{HASIL DAN PEMBAHASAN}

Kegiatan pemberdayaan siswa yang dilakukan dengan strategi model promosi kesehatan untuk menanggulangi menyebarnya penularan Covid-19 di lingkungan sekolah madrasah Aliyah Qamarul Huda dilaksanakan pada pertengahan bulan maret 2021. Siswa yang terlibat dalam kegiatan ini diharapkan kedepannya dapat menjadi kader (agent) untuk dapat mempromosikan kesehatan dan pencegahan Covid-19 dengan menerapkan protokol 5M di lingkungan sekolah MA Qamarul Huda. Selanjutnya kegiatan dilanjutkan dengan edukasi kepada para peserta dengan menyampaikan materi Covid-19, transmisi penularan Covid-19 dan materi protokol kesehatan pencegahan Covid-19 5M yang disampaikan oleh narasumber Ns. Reza Indra Wiguna, M.Kep dan materi simulasi pembuatan hand sanitizer oleh Ns. Mustamu Kamal Pa'ni, M.Kep, dan materi pelatihan yang terakhir mengenai cara menggunakan masker oleh Ns. Lalu Muhammad Sadam Husen, MKM. Para peserta juga diberikan kesempatan untuk bertanya mengenai hal-hal yang belum dipahami.

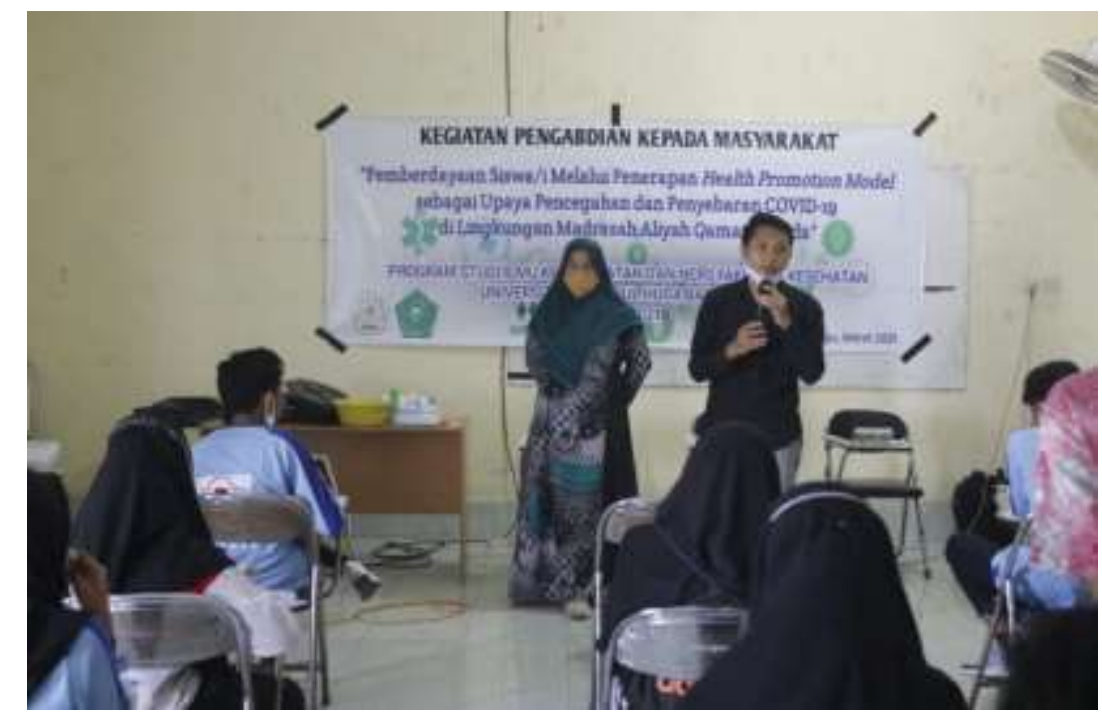

Gambar 2. Materi edukasi Covid-19 dan transmisi penularan Covid-19 di lingkungan sekolah. 

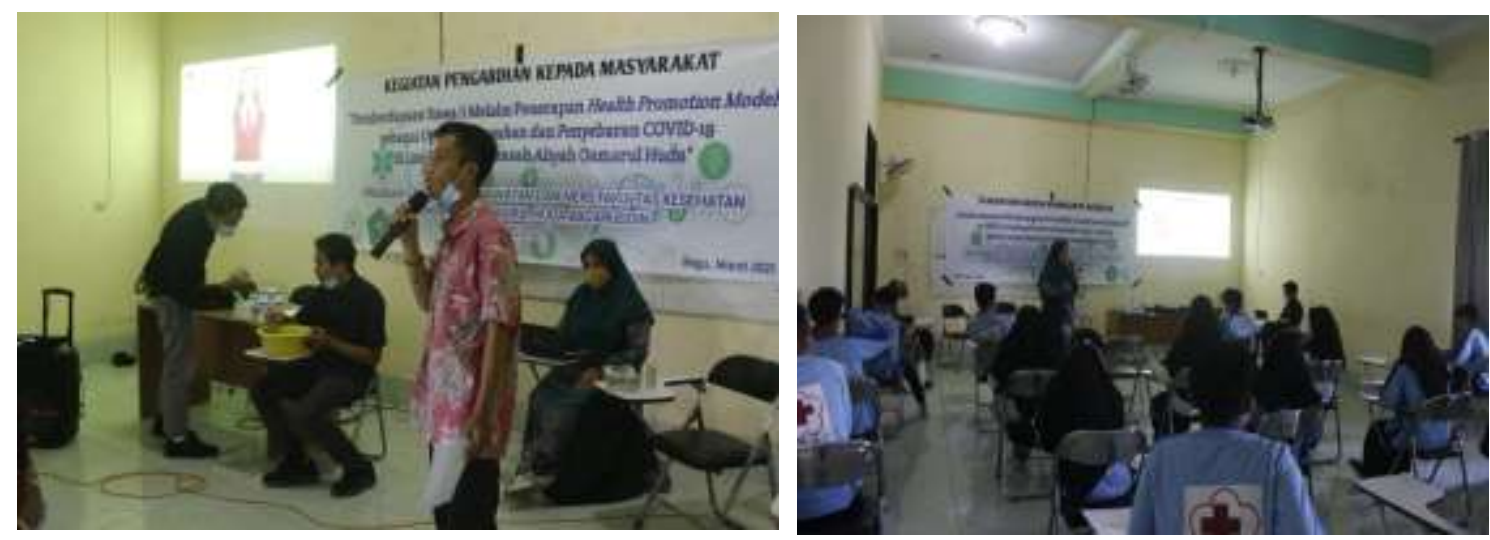

Gambar 3. Pelatihan pembuatan hand sanitizer dan simulasi 6 langkah cuci tangan.

Berdasarkan evaluasi yang dilakukan pada (Gambar 4), didapatkan pengetahuan peserta sebelum kegiatan pelaksanaan pemberdayaan kesehatan memiliki nilai rata-rata tingkat pengetahuan 24,2, Sedangkan setelah pelaksanaan kegiatan pemberdayaan model promosi kesehatan dilakukan, didapatkan nilai tingkat pengetahuan rata-rata meningkat menjadi 27,25

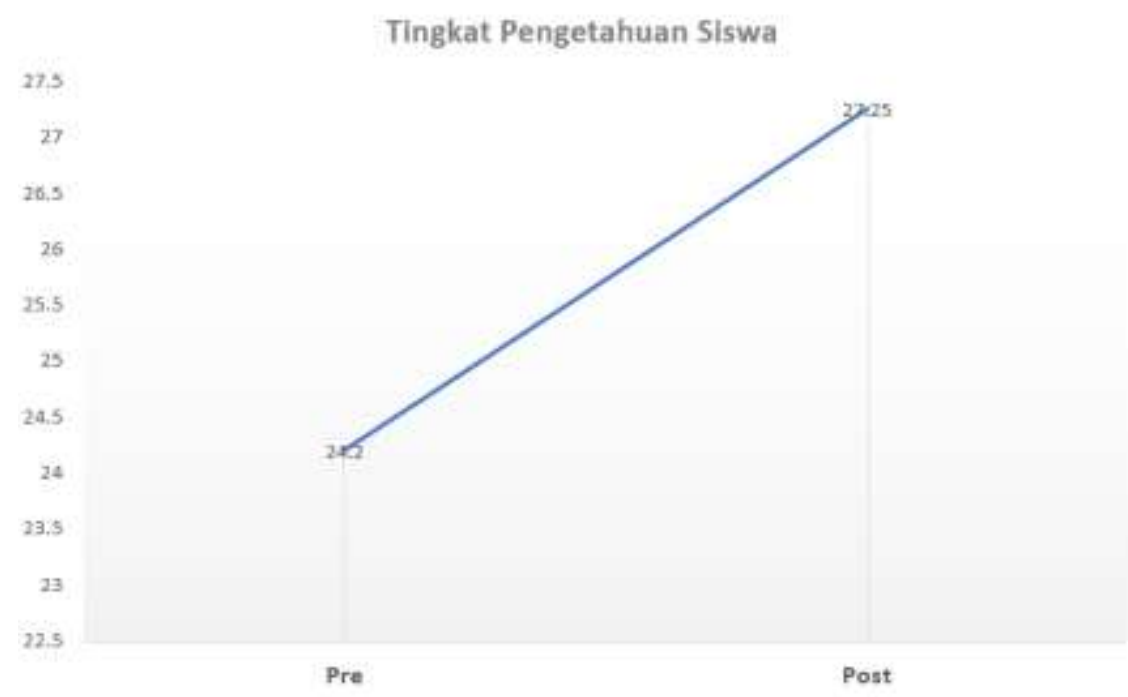

Gambar 4. Perbedaan tingkat pengetahuan siswa sebelum dan sesudah pemberdayaan.

Berdasarkan hasil evaluasi tersebut yang berarti terdapat perbedaan yang signifikan antara pengetahuan peserta sebelum dan setelah kegiatan pemberdayaan model promosi kesehatan. Perubahan ini berdampak positif pada aspek peningkatan pengetahuan bagi para siswa, yang berarti kegiatan pemberdayaan siswa dalam menanggulangi pencegahan Covid-19 di lingkungan madrasah Aliyah Qamarul Huda bermanfaat untuk siswa dan lingkungan sekolah setempat.

Kegiatan pemberdayaan melalui penerapan program Health Promotion Model ini sangat berdampak positif pada kelompok siswa sekolah madrasah Aliyah Qamarul Huda, karena tujuan utama dari kegiatan pemberdayaan ini adalah untuk memberikan edukasi kesehatan dan pelatihan penanggulangan pencegahan Covid-19 pada kelompok siswa madrasah. Kegiatan ini secara tidak langsung juga akan berdampak terhadap kesadaran pihak sekolah selain siswa terutama guru dan staf di lingkungan sekolah madrasah tersebut dalam menjalankan aspek promosi kesehatan protokol pencegahan Covid-19. Oleh karena itu yang menjadi indikator 
keberhasilan dalam kegiatan ini adalah peningkatan pengetahuan dan sikap terhadap upaya penerapan protokol kesehatan 5M di lingkungan sekolah Madrasah Aliyah Qamarul Huda Bagu.

Lingkungan sekolah ditengah situasi pandemi Covid-19 saat ini menjadi perhatian dari segala pihak dikarenakan ditengah situasi pandemi Covid-19 saat ini, sekolah selain berfungsi sebagai tempat pembelajaran juga dapat menjadi ancaman penularan penyakit seperti Covid-19 jika tidak dikelola dengan baik. Adanya perubahan proses pembelajaran di tengah pandemi ini tentu menjadi suatu tantangan tersendiri bagi seluruh lembaga Pendidikan sekolah di Indonesia. Damanik mengungkapkan dalam hasil penelitiannya bahwa lingkungan sekolah yang suasananya positif dan terjaga aman berdampak terhadap motivasi dan hasil belajar peserta didik (Damanik, 2019; Fourianalistyawati \& Listiyandini, 2021).

Kemampuan sekolah dalam menerapkan upaya protokol kesehatan 5M pada seluruh civitas akademika merupakan hal yang sangat prinsip dan merupakan kewajiban sebagai syarat untuk melakukan pembelajaran di masa pandemi Covid-19 saat ini, oleh karena itu kemampuan seluruh civitas akademika baik dari siswa, guru dan pihak sekolah harus berkomitmen dan berupaya penuh dalam menjaga kedisiplinan untuk selalu menerapkan protokol kesehatan yang ketat di lingkungan sekolah. Adanya bekal kemampuan individu siswa dalam menjalankan perilaku kesehatan di tengah situasi pandemi Covid-19 saat ini, secara tidak langsung akan berdampak terhadap pengurangan resiko atau kerugian dari penyebaran penularan Covid-19 di lingkungan sekolah, karena sekolah merupakan tempat yang sangat beresiko terhadap penularan Covid-19 mengingat didalamnya banyaknya siswa dan guru di satu lingkungan tersebut. Hal ini sejalan dengan studi yang dinyatakan oleh Angurahana (2020) yang mengungkapkan bahwa saat ini seluruh sekolah di Indonesia sangat beresiko dan mengalami dampak dari pandemi COVID-19 (Anugrahana, 2020).

Sasaran kegiatan pemberdayaan ini adalah kelompok siswa madrasah Aliyah Qamarul Huda yang tergabung di dalam organisasi PMR, UKS dan OSIM keberadaan mereka sangat penting di tengah pandemi Covid-19 ini dalam penanganan masalah kesehatan yang muncul di lingkungan sekolah, sehingga diharapkan melalui kegiatan pemberdayaan Health Promotion Model (HPM) ini para siswa tersebut dapat menjadi kelompok agen promosi pencegahan Covid-19 kepada temanteman siswa yang lain, hal ini merupakan metode pendekatan promosi kesehatan secara peer group yang lebih efektif karena diantara teman sebanyanya, hal ini sejalan dengan studi yang dilakukan oleh Suriani \& Hermansyah (2015) yang mendapatkan bahwa pendidikan kesehatan melaui tehnik pengumpulan teman sebaya berpengaruh terhadap peningkatan pengetahuan remaja di SMP Negeri 2 Lhoksukon Kabupaten Aceh Utara (Suriani \& Hermansyah, 2014). Hal ini juga diungkapkan oleh Noviyanti (2020) dalam studinya mengindikasikan bahwa dampak Pendidikan kesehatan berbasis gambar visual juga dapat mencegah terhadap kejadian penyakit cacingan di Papua Barat (Noviyanti et al., 2020).

Para siswa yang terlibat dalam kegiatan pemberdayaan HPM ini kedepannya diharapkan dapat menjadi kader kesehatan siswa di sekolah madrasah Aliyah Qamarul Huda, selain memiliki motivasi yang kuat juga memiliki pengalaman terlibat pada pengelolaan organisasi intra sekolah baik di PMR, UKS ataupun OSIM sehingga sangat tepat untuk diberi pelatihan kesehatan khususnya mengenai penanganan dan pencegahan Covid-19 di lingkungan sekolah.

Adanya peningkatan pengetahuan berdasarkan hasil evaluasi mengindikasikan pelatihan ini memberikan dampak yang baik bagi peserta. Untuk meningkatkan pemahaman dan mengasah keterampilan peserta diperlukan pelatihan sejenis yang dilaksanakan secara berkala dan berkelanjutan. Para siswa yang ikut sebagai peserta juga diharapakan dapat berbagi ilmu dengan rekan-rekan siswa lainnya agar terjadi proses kaderisasi, hal inilah yang menjadi tujuan akhir dari program Health Promotion Model ini untuk meningkatkan kesadaran siswa dan kemandirian siswa di lingkungan sekolah dalam mencegah penularan Covid-19. Hasil dari kegiatan ini juga sejalan dengan yang dilaporkan oleh Endang dkk (2012) dalam studinya bahwa pengaruh 
penerapan program Health Promotion Model pada lansia yang hipertensi dapat meningkatkan keaktifan peserta pelatihan, lansia yang menjadi kader kegiatan tersebut mampu mengulangi berbagai macam terapi yang diberikan pada saat pelatihan (Endang et al., 2012; Pender, 2015).

Dampak perubahan sosial secara keseluruhan di lingkup sekolah madrasah Aliyah Qamarul Huda dari kegiatan pemberdayaan pada kelompok siswa ini tentu belum dapat dinilai secara langsung, namun diharapkan kedepannya para siswa ini dapat menjadi agen promosi dengan menerapkan perilaku sehat khususnya penerapan protokol kesehatan $5 \mathrm{M}$ di lingkungan sekolah atau dimanapun mereka berada, karena para siswa yang telah mengikuti kegiatan pemberdayaan telah memiliki pengetahuan dan kemampuan mengenai cara pencegahan Covid19 khususnya di lingkungan sekolah madrasah Aliyah Qamarul Huda.

\section{KESIMPULAN}

Kegiatan pengabdian kepada masyarakat berupa pemberdayaan siswa melalui penerapan program Health Promotion Model sebagai upaya pencegahan dan penyebaran Covid-19 di Lingkungan Madrasah Aliyah Qamarul Huda memiliki dampak positif dalam meningkatkan pengetahuan siswa madarasah mengenai penanganan dan cara pencegahan penularan Covid-19 pada setting sekolah. Pelatihan sejenis diperlukan untuk dilaksanakan secara berkala dan berkelanjutan guna meningkatkan seluruh kemampuan civitas akademika pihak sekolah untuk menunjang jalannya proses kegiatan belajar mengajar secara langsung maupun daring ditengah situasi ancaman pandemi Covid-19 saat ini.

\section{UCAPAN TERIMA KASIH}

Penulis mengucapkan terima kasih kepada Fakultas Kesehatan Universitas Qamarul Huda Badaruddin Bagu yang telah mendukung kegiatan ini dan kepada Pimpinan Madrasah Aliyah Qamarul Huda yang telah mengizinkan kegiatan pemberdayaan ini sehingga dapat terlaksana.

\section{DAFTAR PUSTAKA}

Anugrahana, A. (2020). Hambatan, Solusi dan Harapan: Pembelajaran Daring Selama Masa Pandemi Covid-19 Oleh Guru Sekolah Dasar. Scholaria: Jurnal Pendidikan Dan Kebudayaan, 10(3), 282-289. https://doi.org/10.24246/j.js.2020.v10.i3.p282-289

Damanik, B. E. (2019). Pengaruh Fasilitas Dan Lingkungan Belajar Terhadap Motivasi Belajar. Publikasi Pendidikan, 9(1), 46. https://doi.org/10.26858/publikan.v9i1.7739

Daniel, S. J. (2020). Education and the COVID-19 pandemic. PROSPECTS, 49(1), 91-96. https://doi.org/10.1007/s11125-020-09464-3

Dinkes Prov.NTB. (2021). Data COVID-19 NTB. https://corona.ntbprov.go.id/

Dong, L., \& Bouey, J. (2020). Public Mental Health Crisis during COVID-19 Pandemic, China. Emerging Infectious Diseases, 26(7), 1616-1618. https://doi.org/10.3201/eid2607.200407

Endang, T., Iskandar, A., \& Saryono. (2012). Pengaruh Aplikasi Health Promotion Model Terhadap Peningkatan Kualitas Kelompok Peduli Hipertensi. Jurnal Keperawatan Soedirman, 5(2), 105-114. https://doi.org/https://dx.doi.org/10.20884/1.jks.2012.7.2.363

Fourianalistyawati, E., \& Listiyandini, R. A. (2021). Pengembangan Keterampilan Mindfulness pada Remaja Melalui Pelatihan di Sekolah. 5(3), 694-698.

Kementerian Kesehatan Republik Indonesia, ITAGI, WHO, \& UNICEF. (2020). Survei Penerimaan Vaksin COVID-19 di Indonesia. Satuan Gugus Tugas Penanganan COVID-19, November, 1-26.

Noviyanti, Purwaningsih, \& Dwiranti, F. (2020). Pendidikan Kesehatan Berbasis Gambar Untuk Pencegahan Kecacingan Bersumber Tanah Di Papua Barat. Dinamisia : Jurnal Pengabdian Kepada Masyarakat, 5(1), 169-175. https://doi.org/10.31849/dinamisia.v5i1.4482

Pender, N. J. (2015). Health Promotion in Nursing Practice (Seventh Ed). Pearson Education, Inc. Sagala, S. H., Maifita, Y., \& Armaita. (2020). Hubungan Pengetahuan dan Sikap Masyarakat 
Terhadap Covid-19: A literature Review. Jurnal Menara Medika, 3(1), 46-53. https://jurnal.umsb.ac.id/index.php/menaramedika/index JMM 2020 p-ISSN 2622-657X, eISSN 2723-6862

Suriani, \& Hermansyah. (2014). Pengaruh Peer Group terhadap Peningkatan Pengetahuan Kesehatan Reproduksi Remaja. Jurnal Ilmu Keperawatan, 23-29. http://jurnal.unsyiah.ac.id/JIK/article/view/5186/4352

WHO. (2020). Novel Coronavirus (2019-nCoV): situation report, 19. World Health Organization. https://apps.who.int/iris/handle/10665/330988

Wiranti, W., Ayun Sriatmi, \& Wulan Kusumastuti. (2020). Determinan Kepatuhan Masyarakat Kota Depok terhadap Kebijakan Pembatasan Sosial Berskala Besar dalam Pencegahan Covid-19. Jurnal Kebijakan Kesehatan Indonesia: JKKI, 09(03), 117-124. https://journal.ugm.ac.id/jkki/article/view/58484 